\title{
Nutritional Status of Pregnant Mothers Influence the Health in Adult Life of their Children
}

\author{
E.M. Echarte, Abalo Rocío and A.N. Chisari \\ Instituto de Investigaciones Biológicas, Universidad Nacional de Mar del Plata, Argentina
}

\begin{abstract}
Pregnancy and fetal development are periods of rapid growth and cell differentiation when mother and offspring are vulnerable to changes. Adverse events during development can be linked to an increased risk in developing metabolic diseases. Growth restriction in utero is associated with the development of obesity, hypertension, and diabetes. In these processes, the liver plays a fundamental role.

The aim of this work was to evaluate the effects of a low protein diet in pregnant and lactating mothers on the antioxidant status of the offspring liver. To reproduce real conditions, we used an experimental rat model.

Both ROS and the protective antioxidant systems have to work in coordination to reach a state of redox homeostasis. Excess generation of ROS may result in cell death or different pathological processes. The study also highlights the complex nature of malnutrition injury in which ROS correlates with the hepatic injury in a cause-and-effect manner.

The male offspring with intrauterine growth restriction (IUGR) caused by the isocaloric low-protein diet (8\%) showed decreased liver and body weight at birth. Hepatic cholesterol levels and serum transaminase increase, at weaning (24 day of age).

We observed excess generation of ROS, carbonyl group and lipoperoxidation with that may result in cell death or different pathological processes in the liver.

Conclusion: This study would suggests that liver injury due to accelerated release of toxic oxygen species and impaired antioxidant status may contribute to the high susceptibility to suffer metabolic diseases, that are related to diet in early life and that manifest in adulthood.
\end{abstract}

Keywords: Fetal programming, Low protein diet, Metabolic syndrome, Liver damage, oxidative stress.

\section{INTRODUCTION}

Intrauterine growth restriction (IUGR) affects 3-10\% of pregnancies, and is recognized as the leading cause of intrauterine fetal death and the second leading cause of neonatal Death [1, 2]. Numerous epidemiological studies have demonstrated a strong association between low birth weight and subsequent development of metabolic syndrome, consisting of type 2 diabetes mellitus, obesity, dyslipidaemia, hypertension and coronary artery disease [3-9]. These findings led to the "fetal origins of adult disease hypothesis", which is also described as the developmental origins of health and disease hypothesis [10]. Studies of animal models are consistent with the concept that adverse events in utero predispose the offspring toward the later development of metabolic Syndrome [11]. All these data suggested that although the underlying causes of the metabolic syndrome in humans are complicated and controversial, maternal undernutrition may be a causal factor. Fetal intrauterine growth restriction (IUGR) occurs in humans as a consequence of poor maternal nutrition. IUGR has been associated with the development of adult

*Address correspondence to this author at the Instituto de Investigaciones Biológicas-Universidad Nacional de Mar del Plata, CONICET, Funes $32504^{\circ}$ nivel, CP 7600 Mar del Plata, Argentina; Tel: +54-2234753030;

Fax: +54-2234724143; E-mail: achisari@mdp.edu.ar diseases; this phenomenon is called 'fetal programming'. The association of maladaptive programming with adult disease has been termed the 'Barker hypothesis'. In general, the Barker hypothesis contends that the malnourished fetus is programmed to exhibit a 'thrifty phenotype' with increased food intake and fat deposition and possibly decreased energy output [41].

Underlying molecular mechanisms of metabolic programming remains elusive. Poor nutrition in utero may alter life-long gene expression in major organs and the character of the genotype-environment interaction in later life [10]. There have been ample evidences suggesting that hepatic tissue may play a major role in linking IUGR to the subsequent development of adult diseases [12, 13]. Various experimental animal models have expanded our knowledge of how poor intrauterine nutrition may influence liver development $[14,15]$.

The concept of 'developmental programming' proposes that challenges during an organism's development evoke a persistent physiological response in the offspring [16]. Epidemiological investigations such as those conducted on the children conceived during the Dutch famine of 1944-1945 have highlighted the association between poor maternal nutrition, 
lowered birth weight and subsequent adult disease [17, 18]. Several different experimental animal protocols have been used for the evaluation of developmental programming of metabolism: global nutrient restriction $[19,20]$; or, maternal exposure to an isocaloric low protein diet [21, 22].

However there is little research relating to the lack of protein in pregnant women with metabolic disturbances in a vital organ such as the liver of the offspring.

Individuals who suffered severe malnutrition during the development stage, have a high predisposition to suffer metabolic diseases during adulthood, such as type II diabetes, dyslipidemia, fibrous liver, fatty liver, among others [23].

Given the difficulty and complexity of the regulation of maternal and fetal physiology the physiologist's researchers uses experimental models. These experimental models used are trying to reproduce the form of supply of certain disadvantaged sectors of developing countries, whose own lack protein in their diet.

By contrast, those nutritional circumstances that predispose to Intrauterine Growth Restriction (IUGR) might be due to early childhood exposure. Whereas in some developing countries hunger and inadequate nutritional resources are constant, history has provided many circumstances in which short-term phenomena, whether famine or war, have deprived a cohort of fetuses in utero, only to be followed by a return to normal nutritional status. Therefore we not only have animal models to separate the effect of these constraints, but also natural history epidemiologic work [24].

Animal models clearly demonstrate the effect of poor maternal nutrition on fetal development. Extensive epidemiological and laboratory evidence indicates that a suboptimal environment during fetal and neonatal development in both humans and experimental animals impacts on offspring susceptibility to later development of altered carbohydrate metabolism [25-28].

Actually, there are a few researches relating to the lack of protein in the diet with metabolic disturbances in a vital organ to the body such as the liver.

Reactive oxygen species (ROS) have a crucial role in human physiological and pathophysiological processes. At high concentrations, ROS react readily with proteins, lipids, carbohydrates, and nucleic acids, often inducing irreversible functional alterations or even complete destruction. When ROS were initially integrated into biomedical concepts it was thought that they caused exclusive toxic effects and were associated with pathologies. It is now clear that organisms have also developed methods of utilizing ROS in critical physiological processes [29]. At the cellular level, ROS regulates growth, apoptosis, and other signaling. Overproduction of ROS occurs during stimulated disease conditions, but there is also a genetic component to the propensity for ROS generation [30]. Thus, high and sustained concentrations of ROS can cause damage to many cellular and extracellular constituents, including DNA, proteins and lipids [31]. Free radicals are proposed as key elements in the multifactorial process of having susceptibility to certain diseases and it is predicted that the longer-lived gender should have lower levels of oxidative stress $[32,33]$.

The aim of this work was to evaluate the effects of a low protein diet in pregnant and lactating mothers on the antioxidant status of the offspring liver.

\section{MATERIALS AND METHODS}

\section{Care and Maintenance of Animals}

All procedures were performed in accordance with the guidelines set by the Faculty of Exact and Natural Sciences of Mar del Plata National University Council of Animal Care and upon approval of the Animal Care Committee OCA 2555/14 and 1499/12.

Wistar rats were kept in a room with controlled temperature $\left(25 \pm 1{ }^{\circ} \mathrm{C}\right)$ and with artificial dark-light cycle (light on from 8 am to $8 \mathrm{pm}$ ). Aged 3 months, virgin female rats were caged with one male. Controlled-pregnant, determined by the presence of sperm in the vaginal smears after mating with an adult male for $24 \mathrm{~h}$, were individually housed in plastic cages with free access to water and food. At random to one or two groups to fed either $23 \%$ casein (CTRL=control diet, AIN93G) or an $8 \%$ casein isocaloric diet (LPD=low protein diet group). Food was provided in the form of a large flat biscuit which was retained behind a grill through which the rats nibbled. A weighed excess of feed was provided each day. The day of delivery was considered as day 0 of post-natal life.

To ensure homogeneity of study subjects, litters of over 12 pups or less than 7 were not included in the 
study. On day 24, pups per mother were counted, sex was determined, and body weights of male pups were recorded.

For consistency, only male offspring were used for the study because early-life programming is known to occur in a sexually dimorphic manner [34], which was not the focus of this study.

The animals were euthanized on $d 24$. Blood was collected and processed to obtain serum, which was individually kept at $-80^{\circ} \mathrm{C}$ until assay. Liver was dissected out.

\section{Metabolites Determinations}

\section{Metabolites Determinations}

Serum Total protein, albumin, glucose and cholesterol concentration were determinate by enzymatic assays from Wiener Laboratories, Argentina. Alkaline phosphatase (AP), Serum glutamicoxaloacetic transaminase (SGOT) and serum glutamicpyruvic transaminase (SGPT) were measured by using a commercial kit (WienerLab, Rosario, Argentina) and performed according to the appended protocol. Protein concentration liver was measured with bicinchoninic acid protein assay [35].

\section{Measurement of Liver Redox State}

\section{Detection of Cytosolic ROS Production}

The rate of cytosol $\mathrm{H} 2 \mathrm{O} 2$ production was determined by using the BIOXYTECH $\AA \mathrm{H} 2 \mathrm{O} 2-560^{\mathrm{TM}}$ (Oxis International, Inc.). The assay is based on the oxidation of ferrous ion $(\mathrm{Fe} 2+)$ to ferric ion $(\mathrm{Fe} 3+)$ by hydrogen peroxide $(\mathrm{H} 2 \mathrm{O} 2)$ under acidic conditions. Fe3+ binds to the indicator dye xylenol orange (3,3'bis[N,N-di(Carboxymethyl)- aminomethyl]-ocresolsulfone-phthalein, sodium salt) to form a stable colored complex which absorbance can be measured at $560 \mathrm{~nm}$.

\section{Trolox Equivalent Antioxidant Capacity (TEAC) Assay}

The Trolox Equivalent Antioxidant Capacity (TEAC) assay is based on the scavenging of the 2,2'-azinobis(3-ethylbenzothiazoline-6-sulfonic acid) (ABTS) radical converting it into a colorless product. A reaction mixture containing $20 \mu \mathrm{L}$ of $\mathrm{H} 2 \mathrm{O} 2(100 \mu \mathrm{mol} / \mathrm{L}), 100 \mu \mathrm{L}$ of metmyoglobin $(6.1 \mu \mathrm{mol} / \mathrm{L})$, ABTS $(610 \mu \mathrm{mol} / \mathrm{L})$, and 4 $\mu \mathrm{L}$ of Trolox (concentration range, $0-1.65 \mu \mathrm{mol} / \mathrm{L}$ ) was incubated and subjected to spectrophotometry (was measure at $414 \mathrm{~nm}$ Bio-Tek Instruments).

\section{Lipid Peroxidation Test}

Hydroxyperoxides lípidicos: in the presence of xylenol orage (Fox reagent) 100 umoll, hydroxy butyrate $4 \mathrm{mM}, 25 \mathrm{mM}$ sulfuric ac and $250 \mathrm{uM}$ amomio ferrous sulfate.

The samples are mixed with $900 \mathrm{ul}$ of reagent and $35 \mathrm{ul}$ Fox methanol and then incubated at $\mathrm{T}$ ambient for $30 \mathrm{~min}$. Centifuge $2400 \mathrm{xg}$ for $10 \mathrm{~min}$. The absorbance of the supernatant was measured at $560 \mathrm{~nm})(\varepsilon=$ $4,3 \times 10^{4} \mathrm{M}^{-1} \mathrm{~cm}^{-1}$ )

The samples are mixed with $900 \mathrm{ul}$ of reagent and $35 \mathrm{ul}$ Fox methanol and then incubated at $\mathrm{T}$ ambient for $30 \mathrm{~min}$. Centifuge $2400 \mathrm{xg}$ for $10 \mathrm{~min}$. The absorbance of the supernatant was measured at $560 \mathrm{~nm})(\varepsilon=$ $4,3 \times 10^{4} \mathrm{M}^{-1} \mathrm{~cm}^{-1}$ )

\section{Protein Carbonyl Content}

The reactive carbonyl content of liver proteins was measured according to Ronchi et al. [34]. Briefly, livers were homogenized at $4^{\circ} \mathrm{C}$ in $10 \mathrm{ml} / \mathrm{g}$ fresh weight of cold $0.15 \mathrm{M} \mathrm{NaCl}, 1 \mathrm{mM}$ EDTA and $20 \mathrm{mM}$ Tris- $\mathrm{HCl}$, $\mathrm{pH}$ 7.4. Two $0.75-\mathrm{ml}$ aliquots per sample containing nearly $1 \mathrm{mg}$ protein were mixed with $0.75 \mathrm{ml}$ of $20 \%$ $(\mathrm{w} / \mathrm{v})$ trichloroacetic acid (TCA). The pellets were separated by centrifugation at $6,000 \times \mathrm{g}$ for $5 \mathrm{~min}$, mixed with either $0.75 \mathrm{ml}$ of $2 \mathrm{~N} \mathrm{HCl}$ (blank) or $0.75 \mathrm{ml}$ of $2 \mathrm{~N}$ $\mathrm{HCl}$ containing $0.2 \% \quad(\mathrm{w} / \mathrm{v})$ dinitrophenylhydrazine (DNPH) and agitated for $1 \mathrm{~h}$ at $25^{\circ} \mathrm{C}$ in the dark. Then, they were re-precipitated with $0.75 \mathrm{ml}$ of $20 \%(\mathrm{w} / \mathrm{v})$ TCA, washed three times with ethanol:ethyl acetate (I:I, $\mathrm{v} / \mathrm{v}$ ), dried and mixed with $0.75 \mathrm{ml}$ of $6 \mathrm{M}$ guanidine $\mathrm{HCl}$ at $25^{\circ} \mathrm{C}$. After removing the debris by centrifugation, absorbance at $370 \mathrm{~nm}$ of DNPH-treated samples after subtraction of blanks was assessed. This value was used to calculate the nanomoles of DNPH incorporated per milligramme of protein based on an average absorption of $21 \mathrm{mM}-1 \mathrm{~cm}-1$ for aliphatic hydrazones [36].

\section{Statistical Analysis}

All data are presented as means \pm SD. Data comparison was performed using unpaired two tailed Student's t test (InStat, Graph Pad software). P values lower than 0.05 were considered significant.

Data analyzed include at least three separate experiments. In each experiment three male offspring from 3 different mothers was separated; finally total $\mathrm{N}=$ 27 for each experimental group. 


\section{RESULT}

Effect of Protein Restriction Diet on the Body Weight in Pregnant Mothers and Body Weight of Weaned Pups

The evolution of body weight LPD mothers was characterized by time-related increased. This way was similar than CTRL mothers.

But, the LPD mothers intake more food after 12 days of gestation.

One hundred and two pups (of both sexes) were born from $10 \mathrm{CD}$ mothers and 100 were born from 14 LPD mothers. Interestingly, the number of female pups per mother was similar in the two groups.

The body weight of weaned pups were analyzed, we found a significantly $(p<0.05)$ lower body weight in male pups from LPD $(17 \pm 1.5 \mathrm{~g})$ than from CTRL $(43 \pm 1.2 \mathrm{~g})$ mothers (Figure 1A).

The weight of the livers of the offspring of mothers fed LPD was also significantly lowers than control group $(0.4 \pm 0.1 \mathrm{~g}$ vs $1.6 \pm 0.5 \mathrm{~g})$ (Figure 1B).

\section{Serum Markers of Liver Damage in Offsprings}

At weaning glucose in LPD rats was significantly lower relative to controls. Serum proteins and albumin significantly decrease compared to the control, while

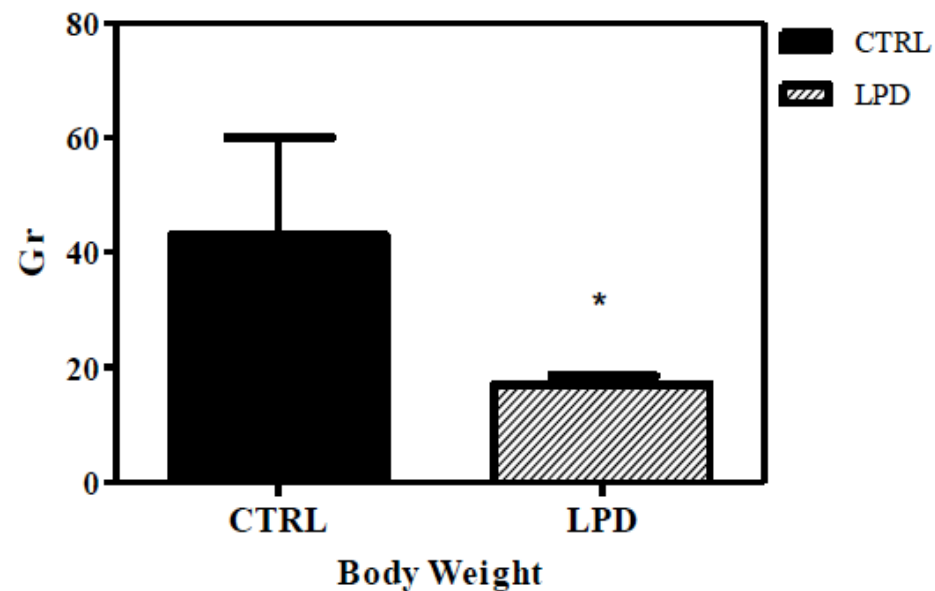

A the levels of cholesterol, AP and transaminase (SGOT and SGPT) were increased (Figure 2).

\section{Relationship between Mother Malnutrition and Oxidative Stress in Liver Offsprings}

LPD increased ROS levels and antioxidant activities.

ROS production increased in the liver of LPD offsprings (33.6 \pm 5 vs $4 \pm 1$ control $\mathrm{P}<0.001$; expressed as $\mathrm{H}_{2} \mathrm{O}_{2} \mu \mathrm{M} / \mathrm{mg}$ prot), (Figure $3 \mathrm{~A}$ ).

\section{Carbonyl-Group Content of Protein}

We examined the extent of liver oxidative stress by measuring the total protein carbonyl content. This was evaluated by the reaction with DNPH. Carbonyl content significantly increased with LPD when compared with CRT, as evidenced by their values $(12 \pm 1.7$ vs $8.1 \pm 1.5$ control, $\mathrm{P}<0.05$ ) (Figure 3B).

\section{Lipid Peroxidation}

The effect of LPD on liver lipid peroxidation was investigated. The LPD increased significantly the TBARS levels of liver compared with CRT $(417.37 \pm 55$ vs $295 \pm 22$ nmoles/g, $p<0.05$ ) (Figure $3 \mathbf{C}$ ).

\section{Antioxidant Activity}

Trolox equivalent antioxidant capacity (TEAC) assay, in LPD animals was higher than CRT group

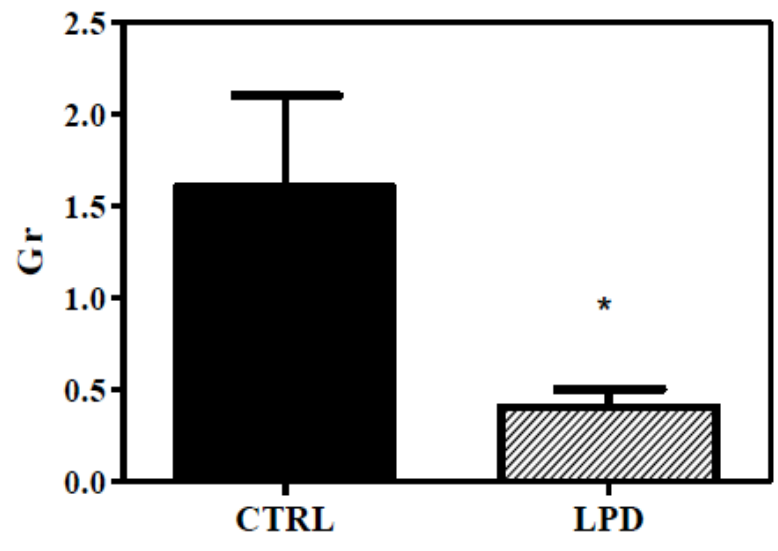

Liver Weight

B

Figure 1: The effect of maternal LPD on liver offspring.

Weaned male pups, at 24 day of age, from pregnant and lactating mothers who fed with Control Diet (group CTRL) and which fed with Low Protein Diet (group LPD) mothers, respectively:

A: Body weight and B: liver weight.

Results were expressed in Gr. The mean \pm SD. *, significant difference $(p<0.05)$ compared to the respective control; $n=27$ for each group. $C T R L=$ dark bars; $L P D=$ clear bars. 


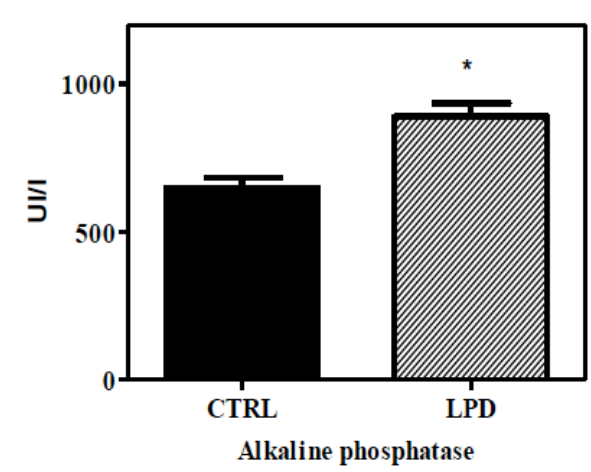

Alkaline phosphatase

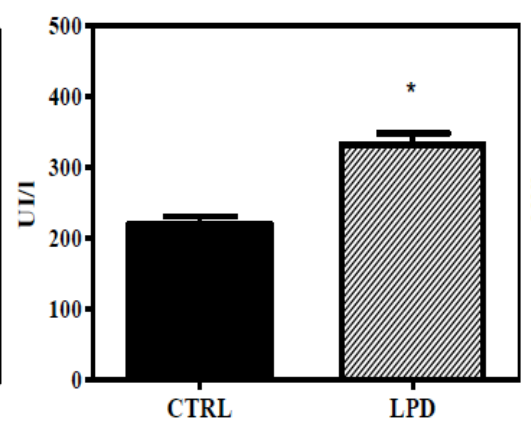

Serum glutamic-0xaloacetic transaminase

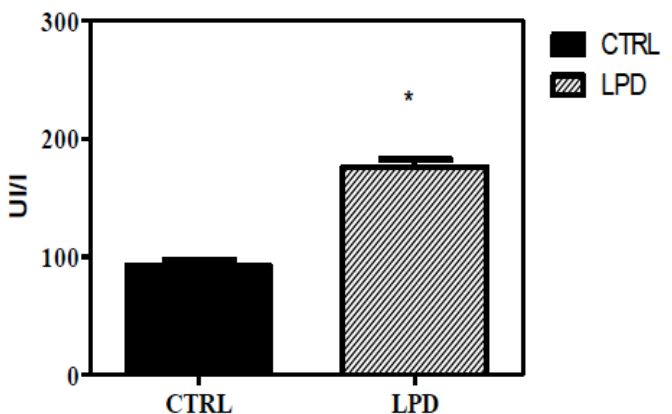

serum glutamic-pyruvic transaminase
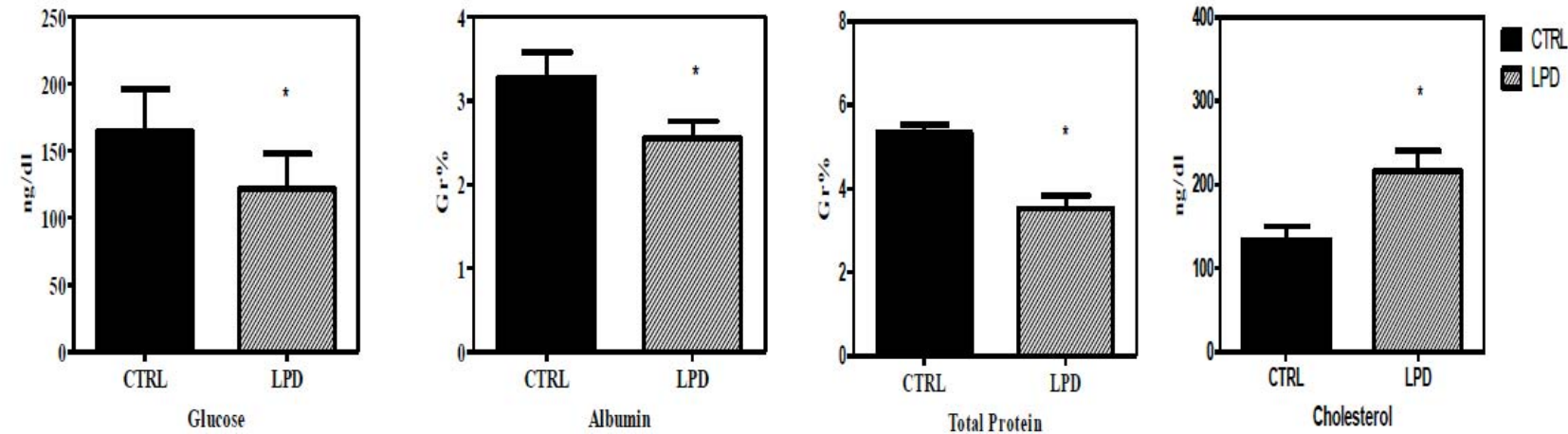

Figure 2: Serum markers of liver damage in offsprings.

Serum Alkaline phosphatase (AP), Serum glutamic-oxaloacetic transaminase (SGOT) and serum glutamic-pyruvic transaminase (SGPT).

Results were expressed in UI/l; were measured by using a commercial kit (WienerLab, Rosario, Argentina). Serum Total protein $(\mathrm{gr} \%)$, albumin $(\mathrm{gr} \%)$, glucose $(\mathrm{ng} / \mathrm{dl})$ and cholesterol $(\mathrm{ng} / \mathrm{dl})$ concentration were determinate by enzymatic assays from Wiener Laboratories, Argentina.

The mean $\pm S D$. * , significant difference $(p<0.05)$ compared to the respective control; $n=27$ for each group. $C T R L=$ dark bars; $\mathrm{LPD}=$ clear bars.

$(278 \pm 21$ vs $187 \pm 12$ umoles Trolox/g liver; $p<0.05)$ (Figure 3D).

\section{DISCUSSION}

During pregnancy, the developing fetus is completely dependent on his mother and maternal environment for nourishment.

Nutrition during the perinatal period is of major importance for proper tissue development and functional maturation. Epidemiological studies in humans have recently suggested that complex metabolic dysfunctions during adulthood, such as glucose intolerance or insulin resistance, could originate from in utero malnutrition.

Recent studies demonstrated that the consequences of inadequate nutrition in utero may extend to adulthood body concerned. The first observations of this phenomenon led to the development of a globally known under the name of 'fetal programming' [31] hypothesis. A variety of animal models were used to study what the impacts of different diet biomolecules on fetal programming of various pathologies were. The most commonly used involved rodents which were placed on low protein diets with high lipid content (high fat) or deficient in micronutrients such as iron [27].

The observations we made were the offspring showed low birth weight, so had a smaller liver [28]. For analysis of liver function results of serum biochemical determinations showed obvious hepatocellular dysfunction reflected in serum levels of the enzymes studied as indicators of the process, GOT and GPT which would suggest that hepatocytes suffered alterations affecting its integrity.

This work examines the evidence of the metabolic disease process involving the liver's oxidative stress induced by protein malnutrition in pregnant and 
A

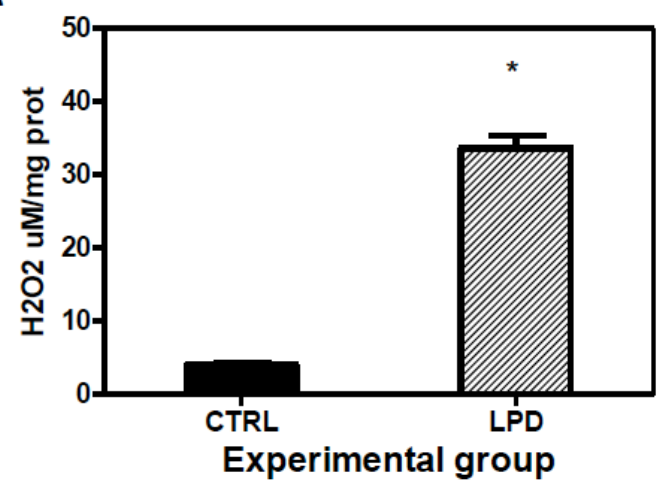

C

\section{Lipid peroxidation}

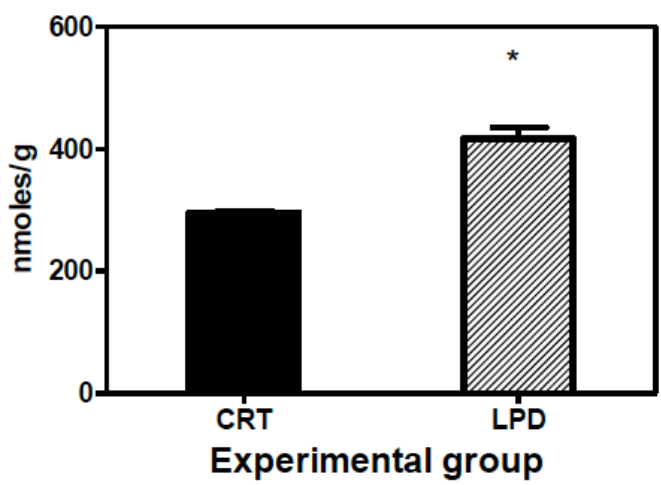

B Carbonyl-group content

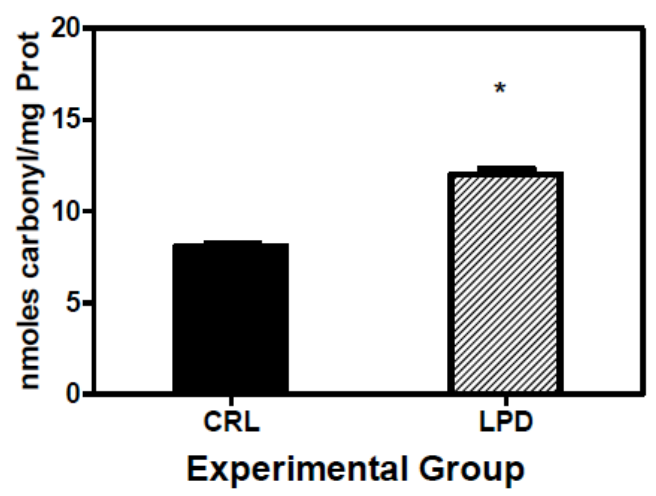

D

Trolox equivalent antioxidant capacity assay

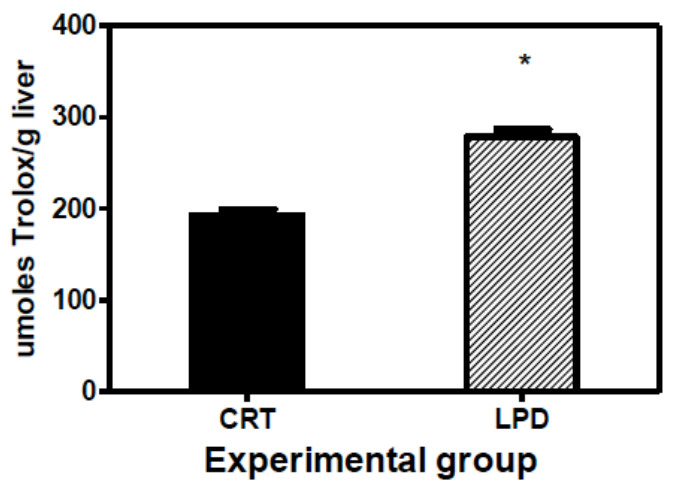

Figure 3: Markers of oxidative stress.

A: Detection of cytosolic ROS production: form a stable colored complex which absorbance can be measured at $560 \mathrm{~nm}$. The mean $\pm S D$. *, significant difference $(p<0.05)$ compared to the respective control; $n=27$ for each group. $C T R L=$ dark bars; $L P D=$ clear bars.

B: Measurement of protein carbonyl content: absorbance at $370 \mathrm{~nm}$. The mean $\pm \mathrm{SD}$. ${ }^{*}$, significant difference $(\mathrm{p}<0.05)$ compared to the respective control; $n=27$ for each group. CTRL= dark bars; LPD= clear.

C: Lipid peroxidation test: The absorbance of the supernatant was measured at $560 \mathrm{~nm}$.

The mean $\pm S D .{ }^{*}$, significant difference $(p<0.05)$ compared to the respective control; $n=27$ for each group. $C T R L=$ dark bars; LPD $=$ clear.

D: Trolox equivalent antioxidant capacity (TEAC) assay: was measure at $414 \mathrm{~nm}$.

The mean $\pm S D$. *, significant difference $(p<0.05)$ compared to the respective control; $n=27$ for each group. $C T R L=$ dark bars; $\mathrm{LPD}=$ clear.

lactating mothers, manifested in the livers of their offspring. Protein malnutrition in pregnant mothers induced liver changes in the oxidative status of their offspring. LPD increased ROS levels and antioxidant enzyme activities. We examined the extent of liver oxidative stress by measuring the total protein carbonyl content and lipid peroxidation. If altered homeostasis for ROS is one essential process that fundamentally contributes to mammalian disease. A rapid increase in ROS production is observed, concomitant with a later enhancement Cell that survive to this stress process have adapted to counteract oxidative damage through increasing its antioxidant defenses. Different intracellular signals are controlled by oxidative stress, with later effects in gene transcription.

Our study showed that levels of oxidative stress and liver peroxide production were increased during malnutrition, findings that are in full accordance with the free radical theory of aging.

According to the Mitochondrial Free Radical Theory of Aging, the rate of mitochondrial ROS production contributes to determine the aging rate [27]. Recently, it has been shown that mitochondria from female Wistar rats produce less ROS than those from males in liver and brain, and their mean life span is $16 \%$ longer [28]. 
In humans, oxidative stress and antioxidant defenses are the sum of a complicated network of enzymatic and non-enzymatic processes. Depending on the stage and severity of diseases, a patient's antioxidant armamentarium may increase as an appropriate response to an oxidant challenge, whereas others may decrease as an indication of unbalanced consumption. In fact, free radicals can affect intracellular signal transduction and gene regulation, resulting in cytokine production essential to the inflammatory process. In many other cases, especially liver diseases, excessive oxidative stress undoubtedly contributes to the progression and pathological findings of disease and serves as a prognostic indicator. Reactive oxygen species are highly reactive molecules that are naturally generated in small amounts through metabolism and could damage cellular molecules such as lipids, proteins or DNA. Oxidative stress plays a major role in many liver diseases.

\section{CONCLUSION}

This shows that if altered homeostasis for ROS is one essential process that fundamentally contributes to mammalian vulnerability to diseases.

In summary, we found high liver injury, high hydrogen peroxide production and less effective antioxidant machinery. Malnourished patients have an increased risk of organ dysfunction and death compared. One factor contributing to this commonly observed phenomenon might be accelerated tissue damage by oxygen free radicals.

This study would suggests that liver injury due to accelerated release of toxic oxygen species and impaired antioxidant status may contribute to the high susceptibility to suffer metabolic diseases, obesity, diabetes, heart damage, among others, that are related to diet in early life and that manifest in adulthood.

While the link between impaired fetal growth and the risk for developing chronic disease in adulthood is undoubtedly strong, the underlying mechanisms are still being elucidated.

Pediatricians could include not only birthweight but also prenatal nutrition per se in the estimation of metabolic risk of infants and children, thus promoting adequate prevention and intervention strategies. Such strategies should include the promotion of breastfeeding and the avoidance of overeating during infancy, not only in small infants but also in normal weight infants born to undernourished mothers, in order to catch up. Furthermore, of utmost importance is the promotion of a healthy lifestyle in adolescent and young adult females who are the pregnant women and mothers of the future.

\section{FINANCIAL SUPPORT}

This work was supported by a grant from UNMDP and CONICET.

\section{CONFLICT OF INTEREST}

None.

\section{REFERENCES}

[1] Gagnon R. Placental insufficiency and its consequences. Eur J Obstet Gynecol Reprod Biol 2003; 110(Suppl 1): S99-S107. http://dx.doi.org/10.1016/S0301-2115(03)00179-9

[2] Pryor J. The identification and long term effects of fetal growth restriction. Br J Obstet Gynaecol 1997; 104: 1116-1122. http://dx.doi.org/10.1111/j.1471-0528.1997.tb10933.x

[3] Ravelli AC, van Der Meulen JH, Osmond C, Barker DJ, Bleker OP. Obesity at the age of $50 \mathrm{y}$ in men and women exposed to famine prenatally. Am J Clin Nutr 1999; 70: 811816.

[4] Leon DA, Johansson M, Rasmussen F. Gestational age and growth rate of fetal mass are inversely associated with systolic blood pressure in young adults: an epidemiologic study of 165,136 Swedish men aged 18 years. Am J Epidemiol 2000; 152: 597-604. http://dx.doi.org/10.1093/aje/152.7.597

[5] Gluckman PD, Hanson MA, Pinal C. The developmental origins of adult disease. Matern Child Nutr 2005; 1: 130-141. http://dx.doi.org/10.1111/j.1740-8709.2005.00020.x

[6] Simmons R. Perinatal programming of obesity. Semin Perinatol 2008; 32: 371-374. http://dx.doi.org/10.1053/i.semperi.2008.08.004

[7] McMillen IC, Robinson JS. Developmental origins of the metabolic syndrome: prediction, plasticity, and programming. Physiol Rev 2005; 85: 571-633.

http://dx.doi.org/10.1152/physrev.00053.2003

[8] Eriksson JG. Epidemiology, genes and the environment: lessons learned from the Helsinki Birth Cohort Study. J Intern Med 2007; 261: 418-425.

http://dx.doi.org/10.1111/j.1365-2796.2007.01798.x

[9] Eriksson JG. Early growth and coronary heart disease and type 2 diabetes: findings from the Helsinki Birth Cohort Study (HBCS). Am J Clin Nutr 2011; 94: 1799S-1802S. http://dx.doi.org/10.3945/ajcn.110.000638

[10] Langley-Evans SC. Developmental programming of health and disease. Proc Nutr Soc 2006; 65: 97-105. http://dx.doi.org/10.1079/PNS2005478

[11] Langley-Evans SC, Bellinger L, McMullen S. Animal models of programming: early life influences on appetite and feeding behaviour. Matern Child Nutr 2005; 1: 142-148. http://dx.doi.org/10.1111/j.1740-8709.2005.00015.x

[12] Warner MJ, Ozanne SE. Mechanisms involved in the developmental programming of adulthood disease. Biochem J 2010; 427: 333-347. http://dx.doi.org/10.1042/BJ20091861

[13] Faienza MF, Brunetti G, Ventura A, et al. Nonalcoholic fatty liver disease in prepubertal children born small for gestational age: influence of rapid weight catch-up growth. Horm Res Paediatr 2013; 79: 103-109.

http://dx.doi.org/10.1159/000347217 
[14] VandeHaar MJ, Moats-Staats BM, Davenport ML, et al. Reduced serum concentrations of insulin-like growth factor-I (IGF-I) in protein-restricted growing rats are accompanied by reduced IGF-I mRNA levels in liver and skeletal muscle. $J$ Endocrinol 1991; 130: 305-312. http://dx.doi.org/10.1677/joe.0.1300305

[15] Thorn SR, Regnault TR, Brown LD, et al. Intrauterine growth restriction increases fetal hepatic gluconeogenic capacity and reduces messenger ribonucleic acid translation initiation and nutrient sensing in fetal liver and skeletal muscle. Endocrinology 2009; 150: 3021-3030. http://dx.doi.org/10.1210/en.2008-1789

[16] Armitage JA, Taylor PD, Poston L. Experimental models of developmental programming: consequences of exposure to an energy rich diet during development. J Physiol 2005; 565: 3-8. http://dx.doi.org/10.1113/jphysiol.2004.079756

[17] Ravelli AC, van der Meulen JH, Michels RP, Osmond C, Barker DJ, Hales CN, et al. Glucose tolerance in adults after prenatal exposure to famine. Lancet 1998; 351: 173-177. http://dx.doi.org/10.1016/S0140-6736(97)07244-9

[18] Roseboom TJ, Vaan der Meulen JHP, Ravelli AC, Osmond C, Baarker DJP, Bleker OP. Effect of prenatal Dutch famine on adult disease in later life. Mol Cell Endocrinol 2001; 185: 93-98.

http://dx.doi.org/10.1016/S0303-7207(01)00721-3

[19] Garofano A, Czernichow P, Bréant B. Beta-cell mass and proliferation following late fetal and early postnatal malnutrition in the rat. Diabetologia 1998; 41: 1114-1120. http://dx.doi.org/10.1007/s001250051038

[20] Chisari AN, Giovambattista A, Perello M, Spinedi E. Impact of maternal undernutrition on hypothalamo-pituitary-adrenal axis and adipocyte functions in male rat offspring. Endocrine 2001; 14: 375-382.

http://dx.doi.org/10.1385/ENDO:14:3:375

[21] Ozanne SE, Smith GD, Tikerpae J, Hales CN. Altered regulation of hepatic glucose output in the male offspring of protein-malnourished rat dams. Am J Physiol 1996; 270: E559-564.

[22] Reusens B, Remacle C. Intergenerational effect of an adverse intrauterine environment on perturbation of glucose metabolism. Twin Res 2001; 4: 406-411. http://dx.doi.org/10.1375/1369052012597

[23] Bavdekar A, Yajnik CS, Fall CH, Bapat S, Pandit AN, Deshpande $\mathrm{V}$, et al. Insulin resistance syndrome in 8-yearold Indian children: small at birth, big at 8 years, or both? Diabetes 1999; 48: 2422-2429.

http://dx.doi.org/10.2337/diabetes.48.12.2422

[24] Kunz LH, King JC. Impact of maternal nutrition and metabolism on health of the offspring. Semin Fetal Neonatal Med 2007; 12: 71-77

http://dx.doi.org/10.1016/j.siny.2006.10.010

[25] Zambrano E, Bautista CJ, Deás M, Martínez-Samayoa PM, González-Zamorano $\mathrm{M}$, Ledesma $\mathrm{H}$, et al. A low maternal protein diet during pregnancy and lactation has sex- and window of exposure-specific effects on offspring growth and food intake, glucose metabolism and serum leptin in the rat. J Physiol 2006; 571: 221-230.

http://dx.doi.org/10.1113/jphysiol.2005.100313

[26] Dahri S, Snoeck A, Reusens-Billen B, Remacle C, Hoet JJ. Islet function in offspring of mothers on low-protein diet during gestation. Diabetes 1991; 40: 115-120. http://dx.doi.org/10.2337/diab.40.2.S115
[27] Petry CJ, Hales CN. Long-term effects on offspring of intrauterine exposure to deficits in nutrition. Hum Reprod Update 2000; 6: 578-586. http://dx.doi.org/10.1093/humupd/6.6.578

[28] Kind KL, Clifton PM, Grant PA, Owens PC, Sohlstrom A, Roberts CT. Effect of maternal feed restriction during pregnancy on glucose tolerance in the adult guinea pig. Am J Physiol Regul Integr Comp Physiol 2003; 284: R140-R152. http://dx.doi.org/10.1152/ajpregu.00587.2001

[29] D'Autreaux B, Toledano MB. ROS as signalling molecules: mechanisms that generate specificity in ROS homeostasis. Nat Rev Mol Cell Biol 2007; 8(10): 813-24. http://dx.doi.org/10.1038/nrm2256

[30] Bedard K, Attar H, Bonnefont J, Jaquet V, Borel C, Plastre O, et al. Three common polymorphisms in the CYBA gene form a haplotype associated with decreased ROS generation. Hum Mutat 2009; 30(7): 1123-33. http://dx.doi.org/10.1002/humu.21029

[31] Droge W. Free radicals in the physiological control of cell function. Physiol Rev 2002; 82(1): 47-95.

[32] Becknneth B. and Ames Bruce N. The Free Radical Theory of Aging Matures. Physiol Rev 1998; 78(2).

[33] Vina J, Borras C, Gambini J, Sastre J, Pallardo FV. Why females live longer than males? Importance of the upregulation of longevity-associated genes by oestrogenic compounds. FEBS Lett 2005; 579(12): 2541-5. http://dx.doi.org/10.1016/j.febslet.2005.03.090

[34] Gabory A, Attig L, Junien C. Sexual dimorphism in environmental epigenetic programming. Mol Cell Endocrinol 2009; 304: 8-18. http://dx.doi.org/10.1016/j.mce.2009.02.015

[35] Chisari AN, Sancho P, Caja L, Bertran E, Fabregat I. Lack of amino acids in mouse hepatocytes in culture induces the selection of preneoplastic cells. Cell Signal 2012; 24: 325332.

http://dx.doi.org/10.1016/j.cellsig.2011.09.018

[36] Caballero VJ, Mendieta JR, Giudici AM, Crupkin AC Barbeito CG, Ronchi VP, Chisari AN and Conde RD. Alternation between dietary protein depletion and normal feeding cause liver damage in mouse. J Physiol Biochem 2011. 67: 43-52. http://dx.doi.org/10.1007/s13105-010-0047-1

[37] Barja G. Free radicals and aging. Trends Neurosci 2004; 27(10): 595-600.

[38] Borrás C, Sastre J, García-Sala D, Lloret A, Pallardó FV, Viña J. Mitochondria from females exhibit higher antioxidant gene expression and lower oxidative damage than males. Free Radic Biol Med 2003; 34(5): 546-52.

[39] Spinedi E, Gaillard RC, Chisari A.Sexual dimorphism of neuroendocrine-immune interactions. Front Horm Res 2002; 29: $91-107$

http://dx.doi.org/10.1159/000061059

[40] Chisari AN, Giovambattista A, Perelló M, Gaillard RC, Spinedi ES. Maternal undernutrition induces neuroendocrine immune dysfunction in male pups at weaning. Neuroimmunomodulation 2001; 9(1): 41-8. http://dx.doi.org/10.1159/000049006

[41] Barker DJ, Eriksson JG, Forsen T, et al. Fetal origins of adult disease: strength of effects and biological basis. Int $\mathrm{J}$ Epidemiol 2002; 31: 1235-1239. http://dx.doi.org/10.1093/ije/31.6.1235 